\title{
Let Them Talk as "Encyclopedia of Russian Life": Latent «Accursed Questions» on Russian Television (2017)
}

\author{
Irina Volkova ${ }^{1, *}$, Leila Algavi ${ }^{2}$, Shuanat Kadyrova ${ }^{2}$ and Natalya Rastorgueva ${ }^{2}$ \\ ${ }^{1}$ RUDN-University, Department of Mass Communication, 117198, Miklukho-Maklaya str., 6, Russian Federation. \\ ${ }^{2}$ RUDN-University, Department of Theory and History of Journalism, 117198, Miklukho-Maklaya str., 6, Russian Federation.
}

\begin{abstract}
International Research Group KVAR performs the first of studies about media influence on the transformation of sociocultural matrix, within which a deep society regulation takes place. For citizens of the Russian Federation, TV is a main source of information about events. Whereas for sociologists and philologists federal channels are unique basic institutions that provide: reproduction of socially significant patterns of citizen's thoughts and behavior; integration of society on the basis of common values. TV Shows on central channels are constantly reaching the top of media credibility rating: 3/4 of Russians (75\%) trust them. They help to create circulation of meanings - TV proposes the values, audience reproduces and modifies them. Thus, we have chosen a Russian TV show "Pust' Govoryat"(Let Them Talk) that presents all the things "that interest everyone" by» exploring intimate issues of a particular person, a family". Authors of this work seek to find out what "interests everyone" in the Russian society. This article includes first results of the research. Latent Theme Identification analysis of transcripts from every episode of the show for 2017 has led to a conclusion that the Russians see a family as a system-forming value concept, words like "child", "children" were used mostly in "Let Them Talk" in 2017. Furthermore, our analysis has established a value paradox: "child", while being an important part of narrative, plays out the role of "McGuffin" (A. Hitchcock)
\end{abstract}

\section{Introduction}

More than one and a half centuries ago, in 1848, renowned critic Vissarion Belinsky introduced the concept of "Encyclopedia of Russian Life", which was applied by him to the verse novel of A. Pushkin "Eugene Onegin". In his mind, encyclopedia of Russian Life is a "true, right and full" picture of "Russian society in one of phases of its formation and development" [1], since it reflects both the male side of Russian life, in the person of the male protagonists, and the female one (the female main characters of a novel).

One hundred and seventy years have passed since then, the Russian society has dramatically changed in the course of its formation, and each time its history was rewritten according to the new technologies and new reality. What can be considered as modern "encyclopedia of Russian life", being able to give a complete and correct idea of Russian society at a certain stage of its development and reflect the prevailing values of life of both sexes? The answer is clear - it should be top rated television program. It should be TV, because not only this type of media remains to be the main source of news about various events for the Russian citizens, but television programs on federal channels are leading in media credibility rating: three quarters of Russians (75\%) trust them [2, 3]. Through the mechanism of television framing, the circulation of meanings is created [4] - television translates values, the audience reproduces and modifies them in the format of talk show [5].

Thus, the most likely candidate in the "encyclopedia of Russian life" at this stage from our point of view is the TV show "Let Them Talk" (LTT), broadcasted on federal state channels since 2001. The concept of the show was based on NBC's "The Jerry Springer Show", which became popular due to the discussion of "dicey" topics such as prostitution and adultery [6]. Since its first broadcast, the Russian program has changed its name several times and corrected the concept of broadcasting.

This is the top-rated talk show of the " Channel One" (see Table 1) to this date, which is broadcasted on prime time four times a week, before the main newscast program "Vremya"(“Time"), with which the generation of Russian decision makers has grown.

Thus, "Let them talk" is the most important empirical source for forming ideas about the state of Russian society; about the problems that worry the society or are being imposed on it. 
Table 1. Weekly rating of «Let Them Talk» among other entertainment media of Russian television (according to the data of «Mediascope»).

\begin{tabular}{|c|c|c|c|c|}
\hline № & $\begin{array}{c}\text { Premiere } \\
\text { date }\end{array}$ & Position & Rating \% & $\begin{array}{c}\text { Total } \\
\%\end{array}$ \\
\hline 1 & 05.01 .2017 & 4 & 4.60 & 12.90 \\
\hline 2 & 09.01 .2017 & 1 & 6.80 & 18.30 \\
\hline 3 & 17.01 .2017 & 2 & 6.40 & 17.70 \\
\hline 4 & 25.01 .2017 & 1 & 6.70 & 18.60 \\
\hline 5 & 31.01 .2017 & 1 & 6.30 & 17.60 \\
\hline 6 & 07.02 .2017 & 2 & 6.10 & 16.60 \\
\hline 7 & 16.02 .2017 & 3 & 6.20 & 17.20 \\
\hline 8 & 20.02 .2017 & 3 & 7.10 & 19.60 \\
\hline 9 & 06.03 .2017 & 2 & 6.00 & 16.90 \\
\hline 10 & 14.03 .2017 & 3 & 6.10 & 17.30 \\
\hline 11 & 23.03 .2017 & 3 & 6.10 & 17.20 \\
\hline 12 & 27.03 .2017 & 3 & 6.40 & 17.50 \\
\hline 13 & 04.04 .2017 & 2 & 5.80 & 16.50 \\
\hline 14 & 10.04 .2017 & 3 & 5.50 & 15.70 \\
\hline 15 & 18.04 .2017 & 2 & 5.60 & 16.50 \\
\hline 16 & 26.04 .2017 & 1 & 6.20 & 18.10 \\
\hline 17 & 03.05 .2017 & 1 & 6.20 & 19.20 \\
\hline 18 & 11.05 .2017 & 3 & 5.20 & 15.80 \\
\hline 19 & 15.05 .2017 & 2 & 4.80 & 14.90 \\
\hline 20 & 22.05 .2017 & 2 & 4.80 & 15.00 \\
\hline 21 & 01.06 .2017 & 2 & 4.70 & 15.20 \\
\hline 22 & 06.06 .2017 & 1 & 5.30 & 17.10 \\
\hline 23 & 14.06 .2017 & 1 & 4.70 & 15.90 \\
\hline 24 & 27.06 .2017 & 1 & 5.20 & 18.20 \\
\hline 25 & 04.07 .2017 & 1 & 4.70 & 16.40 \\
\hline 26 & 10.07 .2017 & 1 & 5.20 & 18.10 \\
\hline 27 & 17.07.2017 & 1 & 4.60 & 16.00 \\
\hline 28 & 24.07 .2017 & 1 & 4.90 & 17.40 \\
\hline 29 & 31.07 .2017 & 1 & 4.50 & 15.90 \\
\hline 30 & 08.08 .2017 & 1 & 4.70 & 16.80 \\
\hline 31 & 14.08 .2017 & 1 & 6.10 & 21.00 \\
\hline 32 & 24.08 .2017 & 2 & 4.50 & 14.90 \\
\hline 33 & 29.08 .2017 & 5 & 4.30 & 13.80 \\
\hline 34 & 06.09 .2017 & 4 & 4.70 & 14.50 \\
\hline 35 & 11.09 .2017 & 5 & 4.30 & 12.90 \\
\hline 36 & 21.09 .2017 & 3 & 4.90 & 15.60 \\
\hline 37 & 28.09 .2017 & 4 & 5.10 & 15.20 \\
\hline 38 & 05.10 .2017 & 3 & 5.50 & 16.30 \\
\hline 39 & 09.10 .2017 & 3 & 6.00 & 17.20 \\
\hline 40 & 19.10 .2017 & 2 & 6.10 & 17.70 \\
\hline 41 & 23.10 .2017 & 2 & 6.00 & 16.80 \\
\hline 42 & 01.11 .2017 & 2 & 5.80 & 16.70 \\
\hline 43 & 07.11 .2017 & 2 & 5.80 & 16.30 \\
\hline 44 & 13.11 .2017 & 2 & 6.20 & 17.80 \\
\hline 45 & 20.11 .2017 & 1 & 7.20 & 20.40 \\
\hline 46 & 29.11 .2017 & 1 & 6.40 & 18.20 \\
\hline 47 & 04.12 .2017 & 1 & 7.90 & 22.30 \\
\hline 48 & 12.12 .2017 & 2 & 5.60 & 16.70 \\
\hline 49 & 19.12 .2017 & 2 & 6.20 & 18.10 \\
\hline 50 & 25.12 .2017 & 4 & 6.40 & 18.70 \\
\hline
\end{tabular}

\section{Methods}

In our study, we proceeded from the premise that any public scandal, i.e. an emotional discussion involving a large number of people, is a valuable sociological material. "Emotionally charged public discussion never comes out of nothing. But it is not in the sense that there is no smoke without fire. The discussed fact itself could never exist, but if people put their souls in some sort of discussion, then there is a certain problem that they would discuss under various pseudonyms. Whatever alias are used, the problem will always be the genuine" [7].

To find out the actual problems, the real topics of the discussion, we resorted to quantitative content analysis and the identification of hidden themes [8].

The study was conducted in two stages. During the first, with the help of Advego program, we identified the semantic cores of the transcripts of each episode (fragment) of the show for 2017, which were then combined into a single table. Thus, the quantification of the micro-representation was carried out, which made it possible to determine how popular one or another microtopic is. During the second stage, we selected the most relevant ones and grouped them into separate blocks larger topics (more details can be found in Appendix 1 in the additional file). As a result, we got an idea of what problems program producers, broadcasters, experts and guests in the studio and, judging by the ratings, viewers really "concern all without exception".

\section{Results}

Analysis of empirical material has shown that the main theme of the program is the family in its traditional sense. The concept of «family» is multicomponent. The first three places by the number of references are occupied by the words «child / children» (4360), «mom (mother)» (2285), «dad (father)» (1860) and «family» (1455). Family values are understandable and universal with most people. Thus, the audience gets the opportunity to identify itself with the characters, establish an emotional connection with them.

Meanwhile, the figures show that blood relationship (Consanguinity) has the greatest importance for the audience of "Let Them Talk" [9]. Nouns that are pointing to kinship relations, for example, «mom (mother)», «dad(father)», «son» (1040), «daughter» (1113), «parent» (586), «grandmother» (438) , «sister» (340), «brother» (265), «grandfather» (131) and «DNA» (257), are used five times more often than nouns denoting marital relations: «wife» (718), «husband» (575), «marriage» (251), «spouse» (209), «wedding» (168), «divorce» (155). Here is another example for greater clarity; the word "wife» is used in 105 episodes of the 2017 season, the word "mother" in 151. For the sake of objectivity, we do not include neither in the first or second rows semantically close to them: «love» (569), «man» (670), «woman» (1183), «relationship» (800), «boy» (462), «girl» (625), «girlfriend» (220), and so on.

A vast majority of the annual program cycle (185 episodes) is devoted to family relationships in one form or another. At different times, various episodes would 
take the first place in the weekly ratings of entertainment programs: «The Secrets of Spartak Mishulin: what the DNA test will tell» of November 20, 2017, «Childhood Rocks again» (funny videos on the Internet, the heroes of which were children) of 08.08.2017, «Celebrity BabyBoom 2017» of July 31, 2017, «Denis Voronenkov is alive? Killer for the killer: what is Maksakova silent about? » of 06.27.2017, «Beauty and the Beast: Confession of a movie star. Private secrets of Vladimir Basov» of 24.07.2017, «The posthumous history of the "drunk boy": will Alyosha Shimko be rehabilitated? » of 17.07.2017, «Rejected: the revelations of the former movie stars' daughters-in-law» of 04.07.2017, «Dad Rocks» (funny videos on the Internet, the heroes of which were fathers) of 03/05/2017.

Importance for the Russians of this item is confirmed also by the data of the poll of the Russian Public Opinion Research Center (VCIOM), published on June 17, 2018. According to it, the index of importance of such aspect as «relations in the family» is 98 points (with a possible range from -100 to 100 points) [10].

As a rule, all other sensitive subjects connected with family values to a certain extent, the theme of material welfare, for example. Here is the summary data for the terms within this framework: «money» (825), «flat» (867), «car / vehicle» (421), «inheritance» (111), «bank account» (122). There are words that relate to this concept indirectly: «million» (410), «fortune» (369), «belongings» (348), «Ruble» (224), «testament» (101), «receive» (136), «bill» (119), «to give (a present) » (119), etc. The first place in the weekly rating of entertainment programs was occupied by the «Mishulin's heritage: son or not son?» of 04.12.2017, «Divorce of the year: is Vitalina pregnant?» of 11.29.2017, «The whole truth about the scandalous divorce of Timati» of 25.01.2017.

The money acts as evil source of permanent intrafamily conflicts in the show. In her article, «Reflecting the basic values of modern Russian society in the conceptual and linguistic pictures of the world», Russian researcher Chernikova N. V. pointed out that such representation is generally a characteristic of the Soviet period of development of Russian society, as well as of Russian culture of the 19th and early 20th centuries, where «metaphorical characteristics of money were preserved: money is evil, money is corruption, money is dirt, money is chaos» [11]. In this case, as noted by the researcher, the bourgeois subculture had its own idea of money: «money is conscience, money is mind, money is honor» [11]. The authors of a comprehensive study of Russian media on the subject of «hate speech» in 2002 have also mentioned «distrust of material prosperity, envy of the rich» among the most common characteristics of the modern culture of interpersonal relationships. "The invasion of socialist doctrine in Russia in the second half of the XIX century has only helped the articulation of the national rejection of wealth, private property (as well as the rights of individual, who opposes himself to the majority) and many other values that were native to Western civilization. 〈...> And today many believe that it is "normal" to be poor. That is, there is constant pursuit to be among "their own", but those are preferred to be "poor" [12].

Another area that has a direct relation to the concept of «family» is «health». According to VCIOM, it holds the first place (99 points) [10]. In our case, we find the theme of «health» (165) being transformed into the topic of treatment and the possibilities of modern medicine. In the show's discussion, it is reflected in such words as: «doctor» (404), «hospital» (301), «treatment» (159), «clinic» (153), «maternity home» (50). Among the other words, we also noted: «blood» (322), «DNA» (257), «birth» (210), «operation» (163), «heart» (119), «analysis» (130), «age» (123), «illness» (111), «feeling» (101), etc. Since the episodes referring to the medical treatment are mostly associated with serious diseases, we also attribute to it the topic of «death» (330), which is represented, for example, by such words as «murder» (153), «body» (142), «corpse» (101).

The fourth theme is «theater / performance». The name of this category conditionally means an objective value reference for the audience. It is not about the theater as a kind of art, but about behind-the-scenes intrigues: illegitimate children of actors and singers and their struggle for inheritance, lovers and mistresses of Russian show business representatives. In the second half of the year, a certain trend has emerged - more often than not Russian showbiz «stars» were becoming the show's characters. The predominance of the term «theater» (563), which gave the name to the thematic group, is directly connected with a loud divorce process of an elderly actor and popular in the post-Soviet space theatrical figure with the subsequent division of property and theater bearing his name.

This set of terms also includes the words: «actor / actor» (695), «star (celebrity)» (205). We also refer the following words to conventionally special verbs: «to play» (302), «play (theatrical performance) » (148), «to sing» (158), «to film / shoot» - 330, «to put on a play» 190. Leading positions in the weekly rating for programs were taken by "The main intrigue is revealed" (episode about the results of the DNA of the son of famous artist Spartak Mishulin) of 04.12.2017, «Divorce of the year: is Vitalina pregnant? " (subject was the divorce of the famous artist Armen Dzhigarkhanyan) of 11.29.2017, "The Secrets of Spartak Mishulin: what the DNA test will tell» of 20.11.2017, «Celebrity Baby-Boom 2017» of July 31, 2017, «Beauty and the Beast: Confession of a movie star. Private secrets of Vladimir Basov» of July 24, 2017, «Oliver Stone: how does Putin's voice sound» and «Oliver Stone: an interview with Putin is like a game of chess» of 10.07.2017, Rejected: the revelations of the former movie stars' daughters-in-law» of 04/07/2017, «Denis Voronenkov is alive? Killer for the killer: what does is Maksakova silent about?» of 06.27.2017, «Deep Terror: Alexei Panin at the center of the scandal yet again» of 14.06.2017, «Danka's Heart: Dana Borisova is a drug addict?» of 26.04.2017, «The entire truth about the scandalous divorce of Timati» of 25.01.2017. «Celebrity Baby-Boom 2016» of 09.01.2017.

The fifth group of terms conceptually associated with the «family» can be combined into a general definition of «law and order». Previously mentioned researcher 
Chernikova N.V. notes in her work that their (terms') basic composition of basic values in modern Russia does not change, and law and order are still among them. «Order is a symbol of the welfare of society. However, this actual concept is understood differently by the Russians. It has many subjective interpretations, depending on personal experience and sphere of activity» [11: 181]. According to the number of references within the framework of the discussion, the following words occupy the first place in the show: «court» (462), «expert» (252), «lawyer» (250), «police» (198), «law» (182), «guardianship» (136), «order» (113), «judicial» (106).

At this point, it was harder for researchers to decide with leading episodes of the rating, since in most of the stories the characters require to some extent the restoration of «order» and the observance of «legality» in relation to themselves. And the characters and participants of the program do not really unambiguously interpret the terms «law», «legality», «right», «justice» and «order» [12]. At the same time, each of them is brought into the studio by their own motives and circumstances; hence the ideal «order» and methods for achieving it are expressed by different ideas. In this regard, we will single out only two episodes, where it really is about an offense in terms of the current legislation of the Russian Federation and the adequacy of the measures taken, by both the authorities and participants in the events. "In the middle of the party» of 31.01.2012 - the first of a series of programs about Diana Shurygina, who has accused S. Semenov of rape. "The posthumous story of a "drunk boy": will Alyosha Shimko be rehabilitated?» of July 17, 2012 - another broadcast about a boy, who got ran over by a car, in the posthumous analysis of whom alcohol was found. It should be noted that in spite of the obvious dissimilarity of these issues, their characters were united by declared goals: the requirement of legality and protection of the family's interests / reputation.

\section{Conclusions}

Now a quick glance at the results of the quantitativesemantic analysis of the program is enough to determine that the concept of «family» prevails as a subject of discussion among program participants, and the words «child / children» are the most used in the show «Let Them Talk» in the season of 2017. This leads us to a paradoxical contradiction. It would be logical, in the opinion of the authors, to assume that the following would be the next most popular terms that are cognate to: «education», «learning» and «upbringing». However, we observe the following: «upbringing» is mentioned 51 times, «bring up» - 49, «educate» - 79, "grow up" - 71, «raise» - 39, «study» - 9, «teach» - 29, «learn» - 9, «school» - 14, «teacher»- 48, «teacher (female)» - 41, «teach»-74, «learn»- 116.

The thematical analysis revealed only three episodes in the indicated areas. Partly, these problems, considered in the context of domestic violence, are reflected in the program of 15.09.2017 «Bad education: a schoolteacher beats up a child». At the same time, the nature of the presentation of the material, in our opinion, boils down to the methods of "shock-content", which leads to the discussion circulating around the concrete case and the audience not being ready to consider the issue as a systemic crisis.

A similar situation can be seen in the program of 05.09.2017 titled «I came here to die: the ninth-grader planned an attack on the school in Ivanteyevka for a long time.» Terminologically, the theme of the school is presented broadly. However, as in the first example, the authors of this study note "reportage" in the coverage of a single event without analyzing the problem overall. Similar problems can be found in contemporary Russian feature films about the school [13].

With the same full compliance in its format and functions of the program, «Let Them Talk» also affects the problem of the general decline in the quality of education in society, looking at the example of a sensational online video, where university students were asked to answer some simple questions on the history of Russian culture. One of the respondents accused the creators of the video that the video was incorrectly edited. («In what century was Pushkin born», 04.04.2017).

Thus, we are coming to the conclusion that, while perceiving the child as the main life value, the modern Russian society is not interested in his/her further development, and, despite recognizing the necessity and importance of education and upbringing, only passively expects that these functions will be fulfilled. The child becomes a kind of "self-valuable fact" This allows us to draw a parallel to a certain extent with the popular phenomenon in the world cinema, for which the term "McGuffin" was created by Alfred Hitchcock. «So the "MacGuffin" is the term we use to cover all that sort of thing: to steal plans or documents, or discover a secret, it does not matter what it is. And the logicians are wrong in trying to figure out the truth of a MacGuffin, since it is beside the point. The only thing that really matters is that in the picture the plans, documents, or secrets must seem to be of vital importance to the characters. To me, the narrator, they are of no importance whatever» [14: 138]. Slovene philosopher and cultural theorist Mladen Dolar formulates the nature of this phenomenon in the following way: «The McGuffins signify only that they signify; they signify the signification as such; the actual content is entirely insignificant. They are both at the core of the action and completely irrelevant; the highest degree of meaning - what everybody is after - coincides with an absence of meaning. The object itself is a vanishing point, an empty space; it does not need to be shown or to be present at all - as in Blow-up - an evocation by words is enough. Its materiality is inessential; it suffices to say that we are merely told of its existence» [15: 45]. As for the subject of our study, it rarely appears in the frame of the most episodes, where a discussion about a child in the literal sense is being held.

In some cases, children serve as an instrument for obtaining material wealth. A number of episodes is devoted to the necessity of establishing paternity through the examination of DNA. Child's interests are 
represented by his/her mother, who is, as a rule, not wealthy, and claims are made against men with a high social status, or (in case of their death) against their heirs. (Episode of 07.09.2017 "The Battle for Millions: The Court recognized the new heir of Boris Nemtsov). Children are also used as an argument in favor of awarding various life preferences in numerous conflicts between former spouses - representatives of modern Russian show business («Divorce from mother-in-law: the ultimatum to great Tatiana Vasilieva» of 06.09.2017, etc.). Even the attempt of Timur Eremeev to prove that his father was the late Spartak Mishulin (the fact of realizing himself as a child of the famous father), was regarded by some participants of the show as an aspiration to raise one's own status. («A small tragedy of a big house. Did Spartak Mishulin have a secret son? » of 05.10.2017, etc.). In his answers to opponents, T. Eremeev is more irrational and operates, in essence, with concepts from the group of categories of «consanguinity», about which we were talking in the beginning of this article.

Another important conclusion that was made during our research is that in the overwhelming majority of cases, the role of the initiator of conflict (or its hidden catalyst) belonged to women. Our next research will expand on this interesting subject.

All authors contributed equally to the writing of this paper. All authors read and approved the final manuscript. The authors declare that they have no competing interests.

Below is the link to the electronic supplementary material (as Appendix 1): goo.gl/dWjLhU.

\section{References}

1. V.G. Belinsky, Works by Alexander Pushkin. Article 9, Collected works in three volumes, in Golovenchenko, F. (general ed.) URL: http://az.lib.ru/b/belinskij_w_g/text_0200.shtml (date of access: 23.03.18)

2. Popularity of TV media among Russians is decreasing. REGNUM. URL: https://regnum.ru/ news/2226480.html (date of access: 23.03.18)

3. T. Matza, Cultural Anthropology 24(3), 489-522 (2009)

4. J. Ostbo, Post-Soviet Affairs 33(3), 200-216 (2017)

5. N. Stevenson, Journalism Studies 11(6), 852-873 (2010)

6. P. Lunt and P. Stenner, Media, Culture \& Society 27(1), 59-81 (2005)

7. E.M. Shulman, The Tale of Fisherman and the Fish: Scandal as reflection of changing social norms, Youtube Channel. URL: https://www.youtube.com/watch?v=yTSClJAmrWc (date of access: 11.04.18)

8. R.E. Boyatzis, Transforming Qualitative Information: Thematic Analysis and Code Development (Sage Publications, Thousand Oaks, CA, 1998)
9. I. Souch, Popular Tropes of Identity in Contemporary Russian Television and Film. (Bloomsbury Publishing, USA, 2017)

10. Life Priorities of Russians: Family, Money or Creativity? Russian Public Opinion Research Center URL:https://wciom.ru/index.php?id=236\&uid=1162 64 (date of access: 23.03.18)

11. N.V. Chernikova, Scientific notes of Tambov regional branch of the Russian Union of Young Scientists 2, 175-183 (2014)

12. My tongue... The problem of ethnic and religious intolerance in Russian Media, in Verhovski, A. (ed) (Panorama, Moscow, 2002)

13. A.A. Fedorov, et al, Media Education 4, 206-235 (2017)

14. F. Truffaut, Hitchcock (Faber \& Faber, London, 2017)

15. M. Dolar, Hitchcock's objects, in Žižek, S. (ed), Everything You Always Wanted to Know about Lacan: But Were Afraid to Ask Hitchcock (Verso, London, 1992) 